\title{
Molecular diagnosis of patients with congenital adrenal hyperplasia due to 21- hydroxylase deficiency
}

Tania Mayvel Espinosa Reyes ${ }^{1 *}$ (D), Teresa Collazo Mesa ${ }^{1}$, Paulina Arasely Lantigua Cruz², Adriana Agramonte Machado2, Emma Domínguez Alonso ${ }^{1+}$ and Henrik Falhammar ${ }^{3,4+}$

\begin{abstract}
Background: Congenital adrenal hyperplasia (CAH) is an autosomal recessive group of diseases. 21-Hydroxylase deficiency (21OHD) accounts for between 95 and 99\% of all CAH cases.

Objectives: To characterize the genotype of patients clinically diagnosed with $21 \mathrm{OHD}$ and to identify the most frequent mutations in the Cuban population.

Methods: Cross-sectional descriptive study that included all patients diagnosed with $210 \mathrm{HD}$ from January 2000 to December 2018. For the molecular analysis of the CYP21A2 gene, a protocol was used that used the polymerase chain reaction in 2 stages; in the first stage genomic DNA was amplified and 5 point mutations were detected in the second stage (Intron 2, Deletion of 8 bp, G318X, I172N and P3OL).
\end{abstract}

Results: The 5 point mutations were identified in 31 of the 55 (56\%) studied patients, 16/21 (76\%) in the saltwasting, 12/18 (67\%) in the simple virilizing and 3/16 (19\%) in the nonclassical form. The Intron 2 mutation was the most frequent, followed by G318X and 8 bp deletion. Compound heterozygotes were found in 10 patients, all corresponded to classic forms of the disease.

Conclusions: The causal CYP21A2 gene mutation was detected in 56\% (72\% in classic CAH), which makes the method encouraging. The most frequent mutations observed were Intron 2 and G318X. The detection of mutations offers confirmation of diagnosis, prediction of phenotype and genetic counseling.

Keywords: Genetics, Point mutations, Congenital adrenal hyperplasia

\section{Background}

Congenital adrenal hyperplasia is an autosomal recessive group of diseases. 21-Hydroxylase deficiency (21OHD) is the most frequent cause of CAH accounting for $95-99 \%$ of cases [1-3], and is the result of mutations in the CYP21A2 gene [4]. The CYP21A2 gene is located in the

\footnotetext{
* Correspondence: tania.espinosa@infomed.sld.cu

tEmma Domínguez Alonso and Henrik Falhammar are share the last authorship.

${ }^{1}$ National Institute of Endocrinology, Zapata Street and D, Vedado, 10400 Havana, Cuba

Full list of author information is available at the end of the article
}

highly polymorphic region of the major histocompatibility complex (HLA), on the short arm of chromosome 6 , locus p21.3, accompanied by a CYP21P pseudogene, with which it has a $98 \%$ homology. Moreover, they are located in tandem after the 3 'terminal portion of the 2 genes that code for the fourth complement component (C4A and C4B) [2, 4].

Like all recessive diseases, patients with $\mathrm{CAH}$ have both alleles (maternal and paternal) affected, and only $1 \%$ is the result of a spontaneous mutation. Gene abnormalities are variable and include anything from point mutations to large deletions. The clinical phenotype is

(c) The Author(s). 2020 Open Access This article is licensed under a Creative Commons Attribution 4.0 International License, which permits use, sharing, adaptation, distribution and reproduction in any medium or format, as long as you give appropriate credit to the original author(s) and the source, provide a link to the Creative Commons licence, and indicate if changes were made. The images or other third party material in this article are included in the article's Creative Commons licence, unless indicated otherwise in a credit line to the material. If material is not included in the article's Creative Commons licence and your intended use is not permitted by statutory regulation or exceeds the permitted use, you will need to obtain permission directly from the copyright holder. To view a copy of this licence, visit http://creativecommons.org/licenses/by/4.0/ The Creative Commons Public Domain Dedication waiver (http://creativecommons.org/publicdomain/zero/1.0/) applies to the data made available in this article, unless otherwise stated in a credit line to the data. 
the result of the combination of these abnormalities in the two CYP21A2 alleles with the least affected allele usually determining the phenotype $[3,4]$.

Molecular analysis of the CYP21A2 gene in patients with 21OHD, in North American and European populations, has shown that about $25 \%$ of these patients present macrodeletions of approximately $30 \mathrm{~Kb}$, which include not only much of the $5^{\prime}$ region of the CYP21A2 gene, but also all of the $\mathrm{C} 4 \mathrm{~B}$ gene and 3 ' region of the CYP21P gene, or CYP21A2 gene macroconversions in a similar way to CYP21P. The remaining $75 \%$ have gene microconversions or point mutations (PM) $[5,6]$. The most frequent $\mathrm{PM}$ described in the classical forms are: I172N, R356W and G318X, a change from C to G in intron 2 which produces a splicing acceptor site 12 bases upstream of the normal splicing acceptor site, called $\ln 2$, a deletion of $8 \mathrm{bp}$ in exon 3 that generates a shift in the reading frame and the appearance of a premature stop codon, called Ex3, and three $\mathrm{T}$ substitutions for $\mathrm{A}$ in codons 234-238, that determine a change in the sequence of Lle-Val-Glu-Met amino acids by Asn-Glu-Glu-Lys, called Cluster Ex6 [6, 7]. In the non-classic (NC) form, the most frequent PM described are P30L and V281L, respectively $[8,9]$.

On the other hand, deletions of the CYP21P gene associated with deletions of the $C 4 A$ or $B$ gene have been described in the normal population [8] and duplications of the $C Y P 21 P$ and $C 4 B$ gene are frequently associated with NC 21OHD. Given the high homology between the CYP21 genes and the complexity of the gene locus, the study at the molecular level is difficult. Thus, it is necessary to implement appropriate methodologies and strategies.

CYP21A2 gene mutations have been studied in different ethnic groups, and it has been shown that a small number of mutations is responsible for the majority of $210 H D$ cases [8-11]. Thus, identifying only these few mutations can be used in a simplified and cheaper CYP21A2 mutation analysis which may be more accessible in places with economical restrictions.

In 2005, the neonatal screening program was established in Cuba [12, 13], using 17-hydroxyprogesterone (17OHP) detection in dry blood on filter paper through the neonatal UMELISA Kit [14]. Its main objectives are early diagnosis of the classic form in both genders, to prevent life-treating salt-wasting crisis and to avoid incorrect sex assignment in the newborn.
The implementation of neonatal screening was undoubtedly an important step in the diagnosis and monitoring of patients with $\mathrm{CAH}$ in Cuba. However, only the clinical and biochemical diagnosis was available; the frequency of the different CYP21A2 mutations in our population was not known, making prenatal diagnosis and personalized genetic counseling difficult.

The CYP21A2 gene analysis is a useful complement to predict phenotype as well as confirming the diagnosis [15]. It is also important in situations where the 17OHP concentrations are unclear and in prenatal diagnosis when a child in a family is affected. Genotype may also predict long-term outcomes [16-18].

Thus, the aim of the current study was to characterize the genotype in patients diagnosed clinically with $21 \mathrm{OHD}$ and identifying the most frequent mutations in the Cuban population.

\section{Methods}

A cross-sectional descriptive study was performed of all patients diagnosed clinically with $21 \mathrm{OHD}$ from January 2000 to December 2018 at the National Institute of Endocrinology, Havana, Cuba. The local ethical committee approved the study and informed consents were obtained.

For the molecular analysis of the CYP21A2 gene, a protocol designed and approved by the National Center for Medical Genetics was used. The first stage used a 2-phase Polymerase Chain Reaction (PCR) and in the second stage, 5 different point mutations were detected (Intron 2, 8 bp Deletion, G318X, I172N and P30L). Characteristics of the mutational analysis in the CYP21A2 gene are shown in Table 1.

Statistical analysis was performed using the SPSS program (version 19). Frequency distributions of qualitative variables were obtained, as well as mean (or median) and standard deviation (or interquartile range) according to whether the distribution was normal (or not). A $p$-value of less than 0.05 was considered statistically significant.

\section{Results}

A total of 55 patients underwent CYP21A2 gene mutation analysis to determine the presence of five common point mutations and these were identified in 31 patients (56\%), of which $28 / 38$ (74\%) with classic forms and $3 / 16$ (19\%) NC form. Table 2 present the clinical characteristics of the phenotype groups.

Table 1 Characteristics of the mutational analysis in the CYP21A2 gene

\begin{tabular}{|c|c|c|c|c|c|}
\hline Mutation & Primers & Product of PCR (bp) & Restriction enzyme & Normal & Mutated \\
\hline Intron 2 & P7 P8 & 378 & Hhal & 378 & 24,354 \\
\hline Pro-30-Leu & P5 P6 & 249 & Hhal & 21,228 & 249 \\
\hline $1172 \mathrm{~N}$ & P11P2 & & Taq I & 416 & 394 \\
\hline Deletion 8-bp & P9 P10 & 89 & - & 89 & 81 \\
\hline Gln-318-Stop & P12 P13 & 136 & Pstl & 25,111 & 136 \\
\hline
\end{tabular}


Table 2 Manifestations and clinical signs in 55 studied patients with 21-hydroxylase deficiency

\begin{tabular}{llll}
\hline Phenotype & $\begin{array}{l}\text { Salt-wasting } \\
(\boldsymbol{n}=\mathbf{2 1})\end{array}$ & $\begin{array}{l}\text { Simple virilizing } \\
(\boldsymbol{n}=\mathbf{1 8})\end{array}$ & $\begin{array}{l}\text { Non-classic } \\
(\boldsymbol{n}=\mathbf{1 6})\end{array}$ \\
\hline Age of diagnosis & $13.4 \pm 6.3$ days & $12.8 \pm 3.4$ months & $13.6 \pm 3.7$ years \\
Gender (n) & $18 \mathrm{~F} / 3 \mathrm{M}$ & $10 \mathrm{~F} / 8 \mathrm{M}$ & 0 \\
Hyponatremia and hyperkalemia at presentation (n) & $14 \mathrm{~F} / 1 \mathrm{M}$ & 0 & 0 \\
Neonatal virilization (n) & $17 \mathrm{~F} / 1 \mathrm{M}$ \\
Macrogenitosomy (n) & $2 \mathrm{M}$ & $8 \mathrm{~F}$ & $1 \mathrm{M}$ \\
Scrotal hyperpigmentation (n) & $3 \mathrm{M}$ & $4 \mathrm{M}$ & $1 \mathrm{M}$ \\
Bone age accelerated (n) & $2 \mathrm{~F}$ & $3 \mathrm{~F}$ \\
Early pubarche (n) & 0 & $2 \mathrm{M} / 1 \mathrm{M}$ & $3 \mathrm{~F}$ \\
Hirsutism (n) & 0 & $3 \mathrm{~F}$ & $8 \mathrm{~F}$ \\
Precocious pseudo-puberty (n) & 0 & 0 & 0 \\
Tall stature (n) & 0 & $2 \mathrm{~F} / 1 \mathrm{M}$ & 0 \\
Acne (n) & 0 & $5 \mathrm{~F} / 1 \mathrm{M}$ & $2 \mathrm{~F}$ \\
Menstrual disorders (n) & $1 \mathrm{~F}$ & $1 \mathrm{~F}$ & $6 \mathrm{~F}$ \\
\hline F & & $1 \mathrm{~F}$ & \\
\hline
\end{tabular}

$F$ female, $M$ Male

In relation to the familial reproduction history, 23 (42\%) identified some pathological elements, 10 (19\%) infertility, 9 (16\%) had been referred for spontaneous abortions, 7 (13\%) hirsutism, 5 (9\%) had a history of known $\mathrm{CAH}$ diagnosis in first-degree relatives, 2 (4\%) neonatal death of unknown cause, 2 (4\%) polycystic ovary syndrome and 1 (2\%) atypical genitalia of unknown cause. No consanguinity was present. When the studied patients were analyzed in detail, $22(71 \%)$ detected 1 mutation, 5 (16\%) 2 mutations, 3 (10\%) 3 mutations and 1 (3\%) 4 of the investigated mutations. The details of the five point mutations studied are specified in Table 3.

The most frequent PM in the SW forms was Intron 2 $(9 / 15,60 \%), 4$ of them in homozygosis, 2 in heterozygosity and 3 in compound heterozygosity with other mutations (Homo I172N Hetero Intron 2, P30L and 8pb (1) and Hetero Intron $2 \mathrm{P} 30 \mathrm{~L}$ and $8 \mathrm{bp}$ (2)). Also in the SV form Intron 2 mutation was the most frequent (9/11, 82\%),

Table 3 Frequency of 5 different point mutations found in the three phenotypes of patients with 21-hydroxylase deficiency in the Cuban population

\begin{tabular}{|c|c|c|c|c|}
\hline \multirow[t]{2}{*}{ Point mutations } & \multicolumn{3}{|c|}{ Clinical forms of $\mathrm{CAH}$} & \multirow[b]{2}{*}{ Total } \\
\hline & Salt-wasting & Simple virilizing & Non-classical & \\
\hline Homo Intron 2 & 4 & 2 & - & 6 \\
\hline Homo G318X & 1 & 1 & - & 2 \\
\hline Homo I172N & 1 & - & - & 1 \\
\hline Hetero Intron 2 & 2 & 3 & 1 & 6 \\
\hline Hetero G318X & 4 & 1 & 2 & 7 \\
\hline Hetero I172N & - & - & - & - \\
\hline Homo I172N Hetero Intron 2, p30L and 8pb & 1 & - & - & 1 \\
\hline Homo P30L and 8pb & 1 & - & - & 1 \\
\hline Hetero Intron2p30L and 8pb & 2 & - & - & 2 \\
\hline Homo Intron2 Hetero P30L and 8pb & - & 1 & - & 1 \\
\hline Hetero G318X and $1172 \mathrm{~N}$ & - & 1 & - & 2 \\
\hline Homo Intron2 and Hetero G318X & - & 1 & - & 1 \\
\hline Hetero Intron 2 and $1172 \mathrm{~N}$ & - & - & - & - \\
\hline Hetero Intron2 and G318X & - & 1 & - & 1 \\
\hline Hetero Intron2 and 8pb & - & 1 & - & 1 \\
\hline Total & 16 & 12 & 3 & 31 \\
\hline
\end{tabular}

Homo Homozygous, Hetero Heterozygous 
present in 3 of those in homozygous, 3 in heterozygosis and the rest in compound heterozygosity (Hetero Intron 2 and I172N (1), Hetero Intron 2 and G318X (1) and Hetero Intron 2 and $8 \mathrm{bp}(1)$ ). Finally, in the $\mathrm{NC}$ form (all diagnosed with the $\mathrm{ACTH}$ stimulation test with measurements of 17OHP levels) the causal mutation was identified in 3/16 patients (19\%), 2 heterozygous for G318X and 1 heterozygous for Intron 2. Figure 1 shows the distribution of the identified mutations according to the number of alleles affected, in each of the clinical presentation forms. The most frequent mutation was Intron 2, followed by G318X, deletion of 8 base pairs, and I172N and P30L (Fig. 2).

The presence of single chromosome abnormalities in a group of patients suggest that family members should be studied. Due to laboratory limitations, only in 10 families both parents were studied and in 4 more families only one parent (Table 3 ). When analyzing the 10 heterozygous patients, girls predominated $(8 / 10)$ and 4 of the patients presented with classic forms (Table 4). According to the genotype, they were distributed into three groups, of which G318X was present in 7 of 10 patients (70\%). The segregation of the mutation was 50/50 maternal/ paternal.

\section{Discussion}

This study is the first report regarding the main CYP21A2 mutations causing CAH due to 21OHD in the Cuban population. Of the five point mutations investigated, at least one were identified in 31 of the 55 (56\%) studied patients with clinical diagnosed 21OHD. The Intron 2 mutation was the most frequent, followed by G318X and 8 bp deletion.

$\mathrm{CAH}$ is the most important cause of $46, \mathrm{XX}$ disorder of sexual development (DSD), constituting $87.5 \%$ of all 46 , XX DSD in Cuba [19, 20]. Newborns screening for CAH in Cuba [13] was an important milestone for the early hormonal diagnosis but genetical diagnosis was still an unsolved problem. Molecular genetic studies in $\mathrm{CAH}$ started many years ago [9]. In general, genetic studies are very expensive, which is a limitation for developing countries, such as Cuba. Based on studies on ancestry in the Cuban population [20-24], it has been estimated that our population received a contribution of genes of European origin (72-83\%), African origin (13.8-26\%) and Native American origin (0.8-3.2\%). These results served as a basis for reviewing the frequency of PMs identified in the Spanish population [25] and those recognized with the highest prevalence were chosen to be explore in the present investigation.

Currently, direct analysis of the gene encoding the enzyme 21-hydroxylase is possible, and the detection of gene alterations causing the disease. However, as some studies have shown [26], direct analysis can sometimes

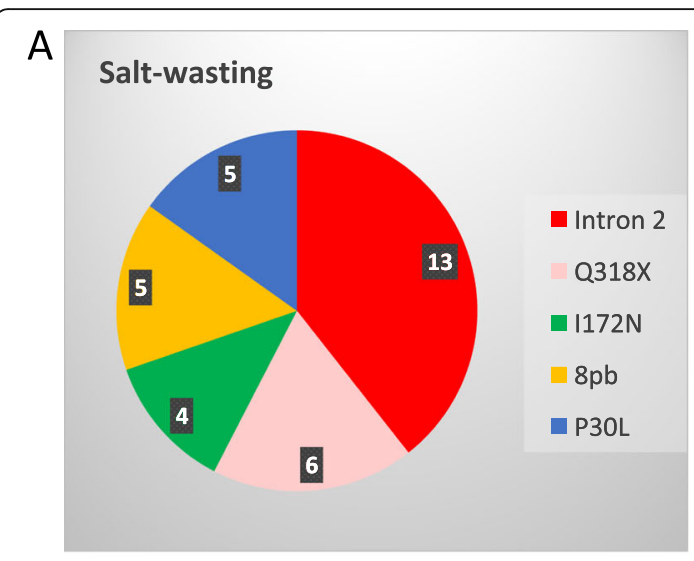

B

Simple virilizing

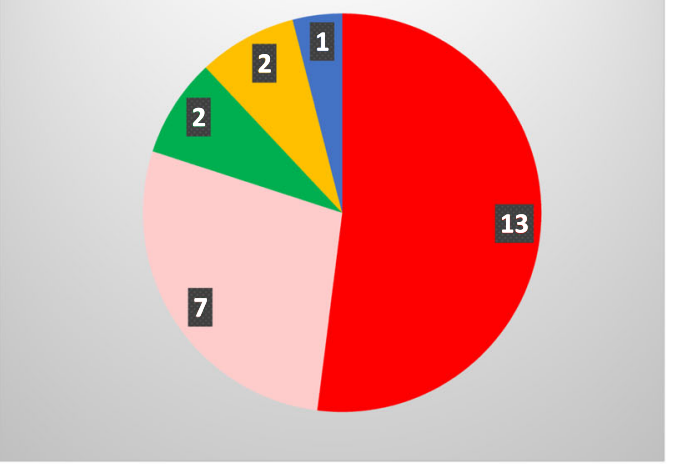

C

Non-classic

2

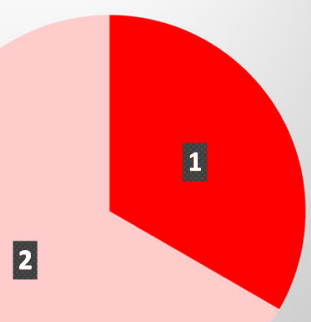

Fig. 1 Distribution of affected alleles according to point mutations found in each clinical phenotype. Panel a Patients with salt-wasting phenotype. Panel b Patients with simple virilizing phenotype. Panel c Patients with nonclassical phenotype

provide limited information due to the presence of complicated rearrangements between CYP21A2 and CYP21P, which make it difficult to determine whether the individual is affected or not.

More than 200 mutations have been described, PMs, small deletions, insertions and complex rearrangements of the gene. The most common mutation appears as a 


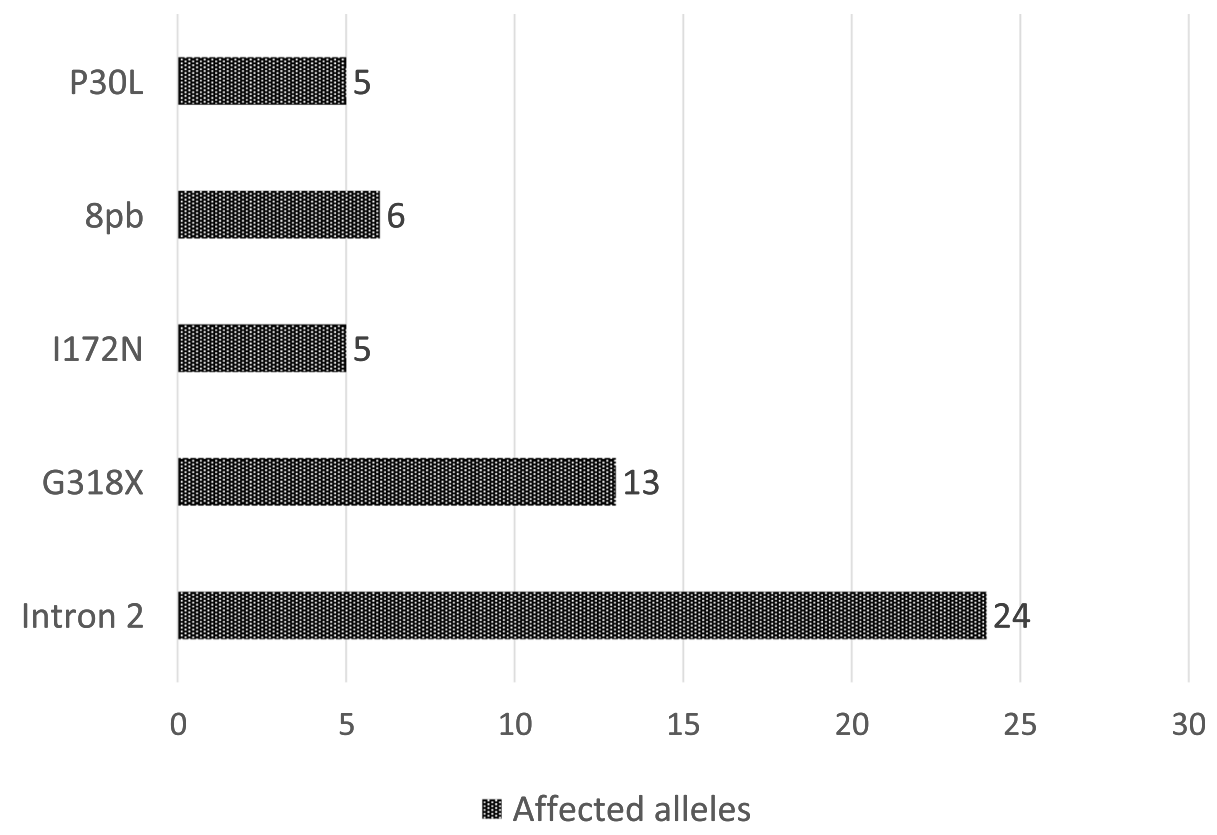

Fig. 2 Affected alleles according to the five explored point mutations

result of one or two types of meiotic recombination events between CYP21A2 and CYP21P: 1) misalignment and uneven crossing, resulting in large DNA deletion, and 2) gene conversion events. Apparently, they give rise to the transfer to CYP21A2 of small mutations present in the pseudogene $[27,28]$.

Throughout the years, the different methodologies used to study the CYP21A2 gene have increased our genetic knowledge of $21 \mathrm{OHD}[4,9,29]$. It has been possible to find characteristic mutations in some populations [29], including unaffected individuals [30]. Therefore, molecular analysis of the CYP21A2 gene is the key to understand the etiology of 21OHD, both in basic science and in clinical diagnosis.

The economic cost of such genetic studies is a limitation for our country; hence, it was only possible to study

Table 4 Analysis of heterozygous patients with 21-hydroxylase deficiency and their families

\begin{tabular}{|c|c|c|c|c|}
\hline Genotype & Sex & Transmission/ Mutation & Clinical expression & Age at diagnosis \\
\hline Intron 2, Del 8pb and P30L & $M^{a}$ & Maternal & $\begin{array}{l}\text { Virilization of external genitalia } \\
\text { Polyuria/Polydipsia. Insipidus diabetes } \\
\text { Dehydration episode }\end{array}$ & 2 years \\
\hline Intron 2 & F & Maternal & Virilization of external genitalia & 30 days \\
\hline Hetero G318X and I172N & $\mathrm{F}$ & $\begin{array}{l}\text { Maternal/ } \\
\text { Heterozygous I172N } \\
\text { Paternal } \\
\text { Heterozygous G318X }\end{array}$ & Virilization of external genitalia & 3 years \\
\hline Hetero Intron 2 and 8pb & M & $\begin{array}{l}\text { Maternal/ } \\
\text { Heterozygous Intron } 2 \\
\text { Paternal } \\
\text { Heterozygous P30L }\end{array}$ & Macrogenitosomy & 3 years \\
\hline G318X and I172N & M & Maternal & $\begin{array}{l}\text { Macrogenitosomy } \\
\text { Scrotal hyperpigmentation }\end{array}$ & 41 days \\
\hline G318X & $\mathrm{F}$ & Paternal & Virilization of external genitalia & First year \\
\hline G318X & $\mathrm{F}$ & Maternal & Early adrenarche & 6 years \\
\hline G318X & $\mathrm{F}$ & Maternal & $\begin{array}{l}\text { Dehydration episode } \\
\text { Virilization of external genitalia }\end{array}$ & 7 days \\
\hline G318X & $\mathrm{F}$ & Paternal & Precocious pubarche & 5 years \\
\hline G318X & $\mathrm{F}$ & Paternal & Precocious pubarche & 6 years \\
\hline
\end{tabular}

a $46 \mathrm{XX}$ karyotype, assigned as male from birth. $F$ Female, $M$ Male 
the presence of five frequent PMs. The strategy used in this study offered encouraging results; with causal mutation being detected in more than half of the affected patients. In particular, in the group of SW patients, mutations causing severe deficit were identified in the majority. It was striking that not all of them had severe mutations in both the paternal and maternal chromosomes. In addition, in some of them, several mutations were observed on the same chromosome, so the total number of mutations detected was higher than that of the unrelated chromosomes studied. For this reason, it is important to carry out, in all cases, both the detection of large rearrangements using the Southern blot technique, and the widest possible analysis of mutations by PCR, to be able to establish an exact genotype.

The most frequent point mutation in the SW form of the Cuban population studied was the intron 2 mutation, which coincides with other studies $[27,31]$. The severe G318X mutation was the second most common mutation, similar to that observed in other populations [32-34]. In addition, the 8 base pair deletion in exon 3 was present in 3 of the SW patients, in all, in compound heterozygosity, and more frequent than others have described [30]. In all, $76 \%$ of the SW cases were characterized genetically.

Moreover, this limited methodology allowed the characterization of 12 of 18 patients (67\%) with the SV form. The frequency of mutations in this phenotype was somewhat peculiar, the frequency of the Intron 2 mutation was present in $64 \%$, much higher than that found in other populations $[26,33,35]$. In all homozygous Intron 2 patients in our study, 4 of them had the SW form and the other 3 the SV form. In some patients it may exist in a certain degree, correct processing of the messenger ribonucleic acid (RNA) [36]. The rest of the patients with SV phenotype presented a similar mutation in compound heterozygosity.

Unlike other studies [31, 37] where the P30L mutation was found with high frequency in patients with the NC form, in our population P30L was only found in 3 patients with classic form, all in compound heterozygosity, which is rare.

Regarding patients with the NC form, molecular genetic analysis allowed only the characterization in about $20 \%$ of patients. It is possible that the remaining patients had other mutations not measured in this study or new mutations that do not exist in the pseudogene. The most common mutation in the NC phenotype is V281L [38], and unfortunately, we were not able to analyze this PM. Hence, new studies to further characterize this group in our population is needed.

Of the 3 patients with $\mathrm{NC}$ forms, 2 presented the G318X mutation in a heterozygous state and 1 was heterozygous for Intron 2. On the other hand, the P30L mutation, which is described as frequent in $\mathrm{NC}$ phenotype, was not found [27, 36]. It should be noted that the 3 patients characterized presented severe mutations in heterozygosity, causing classical forms, which would not have been possible to detect without using these molecular techniques and, moreover, they pose important implications for genetic counseling in these families [39]. Considering that it is an autosomal recessive hereditary disease, it is expected that patients with enzyme deficiency, regardless of their clinical form, presented abnormalities in the 21hydroxylase gene on both chromosomes.

However, when the entire sample of patients was analyzed, it was observed that contrary to expectations, 17 of the patients only presented CYP21A2 gene mutations in 1 of their chromosomes, which obviously complicates performing reliable prenatal diagnosis in this group. When jointly analyzing heterozygous patients, we did not find any common feature that could facilitate prenatal diagnosis. The predominance of girls and the large number of patients with the G318X mutation should be noted.

\section{Conclusions}

The causal CYP21A2 gene mutation was detected in $56 \%$ (74\% in classic $\mathrm{CAH})$, which makes the method encouraging. The most frequent mutations observed were Intron 2 and G318X. The detection of mutations offers confirmation of diagnosis, prediction of phenotype and an personalized genetic counseling.

\section{Abbreviations \\ CAH: Congenital adrenal hyperplasia; 21OHD: 21-Hydroxylase deficiency; DNA: Deoxyribunucleic acid; HLA: Major histocompatibility complex; C4A and C4B: Fourth complement component; PM: Point mutation; SW: Salt-wasting; SV: Simple virilizing; NC: Non- classical; PCR: Polymerase Chain Reaction; DSD: Disorder of sexual development; RNA: Ribonucleic acid}

\section{Acknowledgements}

Adrián de Jesús and Alina Chapé for their laboratory work. Mariela Ramírez Navas for the first translation of the manuscript.

\section{Authors' contributions}

TMER: conceived of the presented idea, design the study, make substantial contributions to acquisition of data, analysis and interpretation of data, and was a major contributor in writing the manuscript. TCM: performed the molecular study. PALC: contributed to analysis of data. AAM: elaborated the consent to participate and conducted the patient interviews. EDA: conducted all statistical analyses. HF: provided critical feedback and helped shape the final manuscript. All authors read and approved the final manuscript.

\section{Funding}

This was an academic investigation with no external funding.

Availability of data and materials

The datasets generated and/or analyzed during the current study are not publicly available, it belongs to the National Institute of Endocrinology. They are available from the corresponding author on reasonable request. 


\section{Ethics approval and consent to participate}

The Ethics Committee of MINISTERIO DE SALUD PÚBLICA INSTITUTO NACIONAL DE ENDOCRINOLOGIA in Havana, Cuba, approved the study. Written formal consent was obtained from patients and/or their guardians.

\section{Consent for publication}

Written informed consent for publication was obtained from all patients. When patients were children their parents or guardians provided written informed consent for publication on their behalf.

\section{Competing interests}

The authors declare that they have no competing interests.

\section{Author details}

${ }^{1}$ National Institute of Endocrinology, Zapata Street and D, Vedado, 10400 Havana, Cuba. ${ }^{2}$ National Center for Medical Genetics, Havana, Cuba. ${ }^{3}$ Department of Molecular Medicine and Surgery, Karolinska Institutet, Stockholm, Sweden. ${ }^{4}$ Department of Endocrinology, Metabolism and Diabetes, Karolinska University Hospital, Stockholm, Sweden.

Received: 1 May 2020 Accepted: 22 October 2020

Published online: 09 November 2020

\section{References}

1. Arlt W, Willis DS, Wild SH, Krone N, Doherty EJ, Hahner S, et al. (CaHASE), U. K.C.a.H.a.S.E.: health status of adults with congenital adrenal hyperplasia: a cohort study of 203 patients. J Clin Endocrinol Metab. 2010;95(11):5110-21.

2. Parsa AA, New MI. Steroid 21-hydroxylase deficiency in congenital adrenal hyperplasia. J Steroid Biochem Mol Biol. 2017;165:2-11.

3. Gidlöf S, Falhammar H, Thilén A, von Döbeln U, Ritzén M, Wedell A Nordenström A. One hundred years of congenital adrenal hyperplasia in Sweden: a retrospective, population-based cohort study. Lancet Diabetes Endocrinol. 2013;1:35-42

4. Falhammar $\mathrm{H}$, Wedell $\mathrm{A}$, Nordenstrom A. Biochemical and genetic diagnosis of 21-hydroxylase deficiency. Endocrine. 2015;50(2):306-14.

5. New Ml, Abraham M, Gonzalez B, Dumic M, Razzaghy-Azar M, Chitayat D, et al. Genotype-phenotype correlation in 1,507 families with congenital adrenal hyperplasia owing to 21-hydroxylase deficiency. Proc Nat Acad Sci U SA. 2013;110:2611-6.

6. El-Maouche D, Arlt W, Merke DP. Congenital adrenal hyperplasia. Lancet. 2017:17:31431-9.

7. Concolino P, Mello E, Minucci A, Giardina B, Capoluongo E. Genes, pseudogenes and like genes: the case of 21-hydroxylase in Italian population. Clin Chim Acta. 2013;424:85-9.

8. Ezquieta B, Beneyto M, Muñoz-Pacheco R, Barrio R, Oyarzabal M, Lechuga JL, et al. Gene duplications in 21-hydroxylase deficiency: the importance of accurate molecular diagnosis in carrier detection and prenatal diagnosis. Prenat Diagn. 2006;26:1172-8.

9. Falhammar $\mathrm{H}$, Nordenström A. Nonclassic congenital adrenal hyperplasia due to 21-hydroxylase deficiency: clinical presentation, diagnosis, treatment, and outcome. Endocrine. 2015:50:32-50.

10. Wedell A. Molecular genetics of 21-hydroxylase deficiency. Endocr Dev. 2011;20:80-7.

11. Fardella C, Poggi H, Soto J. A. Mutations in the CYP21B gene in a Chilean population with simple virilizing congenital adrenal hyperplasia. $J$ Endocrinol Investig. 2000;23:412-6.

12. González EC, Carvajal FM, Frómeta A, Arteaga AL, Castells EM, Espinosa RT, et al. Newborns screening for congenital adrenal hyperplasia in Cuba: six years of experience. Clin Chim Acta. 2013;421:73-8.

13. Carvajal MF, González REC, Espinosa RT, Frómeta SA, Castells MEM, Arteaga YAL et al. Programa cubano de pesquisa neonatal de la hiperplasia adrenal congénita: Una realidad 2005-2014. Disponible en: https://www.google. $\mathrm{com} /$ url? sa $=\mathrm{t} \& \mathrm{rct}=\mathrm{i} \& \mathrm{q}=\&$ \&esrc=s\&source $=$ web\& $\mathrm{cd}=5 \& \mathrm{ved}=2 \mathrm{ahUKE}$ wi5 zfyswNvnAhVHwVkKHapJDfQQFjAEegQICRAB\&url=http\%3A\%2F\%2Fwww. revistaccuba.cu\%2Findex.php\%2Frevacc\%2Farticle\%2Fdownload\%2F296\%2 F296\&usg=AOVVaw1anXJomHATJkOV10WEWH61

14. González EC, Marrero N, Pérez PL, Frómeta A, Zulueta O, Herrera D, et al. An enzyme inmunoassay for determining 17-hydroxyprogesterone in dried blood spots on filter paper using an ultramicroanalytical system. Clin Chem. 2008:394:63-6
15. Speiser PW, Arlt W, Auchus RJ, Baskin LS, Conway GS, Merke DP, et al. Congenital adrenal hyperplasia due to steroid 21-hydroxylase deficiency: an Endocrine Society clinical practice guideline. J Clin Endocrinol Metab. 2018; 103(11):4043-88.

16. Hagenfeldt $K$, Janson PO, Holmdahl G, Falhammar H, Filipsson $H$, Frisen L, Thoren M, Nordenskjold A. Fertility and pregnancy outcome in women withcongenital adrenal hyperplasia due to 21-hydroxylase deficiency. Hum Reprod. 2008;23(7):1607-13.

17. Frisén L, Nordenström A, Falhammar H, Filipsson H, Holmdahl G, Janson PO, et al. Gender role behavior, sexuality, and psychosocial adaptation in women with congenital adrenal hyperplasia due to CYP21A2 deficiency. J Clin Endocrinol Metab. 2009;94(9):3432-9.

18. Falhammar H, Frisen L, Hirschberg AL, Nordenskjold A, Almqvist C, Nordenstrom A. Increased risk of autoimmune disorders in 21-hydroxylase deficiency: a Swedish population-based National Cohort Study. J Endocr Soc. 2019;3(5):1039-52

19. Espinosa RT, García SJ, Carvajal MF, Pérez GC. Trastornos de la diferenciación sexual: 20 años de experiencia. Revista Internacional de Andrología. 2007; 5(3):218-25.

20. Falhammar H. Claahsen-van der Grinten H, Reisch N, Slowikowska-Hilczer J, Nordenström a, Roehle R, Bouvattier C, et al. DSD-LIFE group. Health status in 1040 adults with disorders of sex development (DSD): a European multicenter study. Endocr Connect. 2018;7(3):466-78.

21. Espinosa RT, Hernández BM, Carvajal MF, González RE, Domínguez AE. Influencia de factores perinatales en la pesquisa neonatal de hiperplasia adrenal congénita en Ciudad de La Habana y La Habana. Rev Cuba Endocrinol. 2012;23(1):1-18.

22. Marcheco TB, Fuentes SE, Marín PLC, Gómez CE. Cuba: Estudio de la historia del mestizaje y de las bases genéticas de la pigmentación de la piel utilizando marcadores autosómicos y uniparentales. Anales de la academia de ciencias de Cuba. 2015;5(3) Disponible en: www.revistaccuba.cu/index. php/revacc/article/view/298/298.

23. Ustáriz GCR, Morera BLM, Hernández RP, Estrada del Cueto M, Bencomo HA, García GM, et al. Origen y composición genética de la población cubana. Rev Cuba Hematol Inmunol Hemoter. 2011;27(3):273-82 [citado 2020 Mar 22] ; . Disponible en: http://scielo.sld.cu/scielo.php?script=sci_arttext\&pid= S0864-02892011000300002\&lng=es.

24. Diaz-HO CA, Fernández-de-Cossio ME, Nazabal M, Ferrer A, Roca J, et al. Relationship of type 1 diabetes to ancestral proportions and HLA DR/DQ alleles in a sample of the admixed Cuban population. Ann Hum Biol. 2010;37(6):778-88.

25. Ezquieta B, Oliver A, Gracia R, Gancedo PG. Analysis of steroid 21hydroxylase gene mutations in the Spanish population. Hum Genet. 1995:96:198-204.

26. Kharrat M, Riahi A, Maazoul F, M'rad R, Chaabouni H. Detection of a frequent duplicated CYP21A2 gene carrying a Q318X mutation in a general population with quantitative PCR methods. Diagn Mol Pathol. 2011;20:123-7.

27. The Human Gene Mutation Database. Available at: www.hgmd. cf.ac.uk/ac/ index.php. Accessed July 27, 2018.

28. Mithra L, Narasimhan M, B Ahmed K. Genetics of congenital adrenal hyperplasia and genotype-phenotype correlation. Fertil Steril. 2019; 111(1):24-9.

29. Speiser PW, New MI, Tannin GM, Pickering D, Young Yang S, White PC. Genotype of Yupik Eskimos with congenital adrenal hyperplasia due to 21hydroxylase deficiency. Hum Genet. 1992;88:647-8.

30. Wedell A, Thilén A, Ritzen EM, Stengler B, Luthman H. Mutational spectrum of the steroid 2l-hydroxylase gene in Sweden: implications for genetic diagnosis and association with disease manifestation. J Clin Endocrinol Metab. 1994;78:1145-52

31. Dracopoulou-Vabouli M, Maniati-Christidi M, Dacou-Voutetakis C. The spectrum of molecular defects of the CYP21 gene in the Hellenic population: variable concordance between genotype and phenotype in the different forms of congenital adrenal hyperplasia. J Clin Endocrinol Metab. 2001;86:2845-8.

32. Mathur R, Menon PS, Kabra M, Goyal RK, Verma IC. Molecular characterization of mutations in Indian children with congenital adrenal hyperplasia due to steroid 21-hydroxylase deficiency. J Pediatr Endocrinol Metab. 2001;14:27-35.

33. Lobato MN, Ordoñez-Sanchez ML, Tusie-Luna MT, Meseguer A. Mutation analysis in patients with congenital adrenal hyperplasia in the Spanish population: identification of putative novel steroid 21-hydroxylase deficiency alleles associated with the classic form of the disease. Hum Hered. 1999:49:169-75. 
34. Ezquieta B, Cueva E, Oyarzabal M, Oliver A, Varela JM, Jariego C. Gene conversion (655G splicing mutation) and the founder effect (Gln318Stop) contribute to the most frequent severe point mutations in congenital adrenal hyperplasia (21- hydroxylase deficiency) in the Spanish population. Clin Genet. 2002;62:181-8.

35. Khattab A, Haider S, Kumar A, Dhawan S, Alam D, Romero R, et al. Clinical, genetic, and structural basis of congenital adrenal hyperplasia due to 11 beta-hydroxylase deficiency. Proc Natl Acad Sci U S A. 2017;11:E1933-40.

36. Nordenstrom A, Falhammar H. Management of endocrine disease: diagnosis and management of the patient with non-classic CAH due to 21hydroxylase deficiency. Eur J Endocrinol. 2019;180:R127-R45.

37. Nandagopal R, Sinaii N, Avila N, Van Ryzin C, Chen W, Finkielstain G, et al. Phenotypic profiling of parents with cryptic nonclassic congenital adrenal hyperplasia: findings in 145 unrelated families. Eur J Endocrinol. 2011;164: 977-84.

38. Balsamo A, Baldazzi L, Menabò S, Cicognani A. Impact of molecular genetics on congenital adrenal hyperplasia management. Sex Dev. 2010;4:233-48.

39. Grigorescu-Sido A, Schulze E, Grigorescu-Sido P, Heinrich U, Nistor T, Duncea I. Mutational analysis and genotype-phenotype correlation in patients with classic 21-hydroxylase deficiency from transylvania (northWest Romania). J Pediatr Endocrinol Metab. 2002;15:1505-14.

\section{Publisher's Note}

Springer Nature remains neutral with regard to jurisdictional claims in published maps and institutional affiliations.

Ready to submit your research? Choose BMC and benefit from:

- fast, convenient online submission

- thorough peer review by experienced researchers in your field

- rapid publication on acceptance

- support for research data, including large and complex data types

- gold Open Access which fosters wider collaboration and increased citations

- maximum visibility for your research: over $100 \mathrm{M}$ website views per year

At $\mathrm{BMC}$, research is always in progress.

Learn more biomedcentral.com/submissions 